\title{
Advances in regional anaesthesia and pain management
}

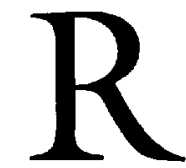

EGIONAL anaesthesia performed for surgery and for postoperative pain management is extremely safe ${ }^{1}$ and has enjoyed a renaissance in recent years. A new local anaesthetic agent has been developed and recently launched in Canada. Block techniques are being refined or newly developed to localise nerve targets more accurately. New clinical knowledge is continuously generated, improving both block efficacy and patient safety. More than ever before, regional anaesthesia is part of a multi-modal approach to perioperative pain management that expedites patient recovery and discharge. This lecture will focus selectively on some of the important new developments of the past five years that have significant clinical relevance in the adult non-obstetrical patient population.

\section{Ropivacaine}

Ropivacaine (Naropin ${ }^{\circledR}$, Astra Canada), a new aminoamide local anaesthetic, made its debut in Canada in 1997. It is the first local anaesthetic prepared isomerically pure in the S-enantiomer form, making it less toxic than bupivacaine in the racemic preparation (containing both $\mathrm{R}$ - and $\mathrm{S}$ - enantiomers).

\section{Toxicity}

Both drugs have similar physical and chemical profiles, but their cardiovascular and central nervous system (CNS) effects differ. Ropivacaine has less potential to depress myocardial contractility and conduction and to trigger ventricular arrhythmia. The fatal cardiotoxic dose ratio in sheep is 1:2:9 for bupivacaine:ropivacacine:lidocaine. A CNS toxicity study showed that human subjects can tolerate a slow infusion of $30 \%$ more ropivacaine than bupivacaine before symptoms occur (mean: $124 \mathrm{mg} v s 99 \mathrm{mg}$ ). ${ }^{2}$ A case of seizure and hypotension has been reported after inadvertent intraarterial injection of $150 \mathrm{mg}$ ropivacaine, but without development of arrhythmia or impaired recovery. ${ }^{3}$ The toxic blood concentration for ropivacaine has not yet been documented in humans.

\begin{abstract}
Anaesthesia
Ropivacaine has been used for anaesthesia for a variety of surgical procedures ${ }^{4}$ and the maximum recommended dose is $2.5-3 \mathrm{mg} \cdot \mathrm{kg}^{-1}$ for peripheral nerve, brachial plexus and epidural blocks. When used in brachial plexus block, ropivacaine $0.5 \%$ and bupivacaine provide equivalent motor and sensory blockade, with comparable onset time, long duration and analgesic efficacy. However, higher concentrations $(0.75 \%-1 \%)$ and doses of ropivacaine are required to achieve the same degree and duration of motor block in epidural anaesthesia when compared with bupivacaine. ${ }^{5}$ It is important to note that the safety margin for ropivacaine narrows if the dose is increased substantially to augment motor block intensity. The addition of epinephrine to ropivacaine is not warranted because it does not alter block intensity or duration. Ropivacaine has not been approved for spinal anaesthesia, thus experience with this application is limited. ${ }^{6}$
\end{abstract}

\begin{abstract}
Analgesia
The greater sensory-motor separation property of epidural ropivacaine makes it an attractive drug for postoperative pain management. So far, studies of epidural ropivacaine for postoperative analgesia have only examined the analgesic efficacy of continuous ropivacaine infusion alone in concentrations of 0.1 , 0.2 and $0.3 \%{ }^{7}$ Analgesic efficacy proved dose-dependent, but even with $0.3 \%$ at $10 \mathrm{ml} \cdot \mathrm{hr}^{-1}$, systemic opioid supplementation was necessary to achieve satisfactory analgesia. Systemic accumulation over a 24-hr period of infusion at $10-30 \mathrm{mg} \cdot \mathrm{hr}^{-1}$ produced no systemic toxicity and low plasma concentrations. ${ }^{8}$ However, motor block developed over time even with lower concentrations. ${ }^{9}$ Thus, epidural infusion of ropivacaine alone is not a useful postoperative management technique. Alternatively, $0.1 \%$ combined with epidural opioid might produce adequate analgesia with lower risk of motor block but study results are pending. At present, the $0.2 \%$ solution is commercially available as a Polybag $^{\oplus}$ epidural infusion kit with $100-\mathrm{ml}$ and $200-\mathrm{ml}$ doses.
\end{abstract}




\section{Intravenous regional anaesthesia}

New techniques of IVRA for upper extremity blocks are applied to improve patient safety and post-block analgesia. A recent survey of North American anaesthetists revealed that $66 \%$ of the respondents encountered minor local anaesthetic-related side effects in patients undergoing IVRA, 14\% of the anaesthetists reported seizures and $1.2 \%$, cardiac arrest. ${ }^{10}$ Systemic toxic complications can occur as a result of considerable leakage or release of local anaesthetic when the tourniquet is inflated or deflated respectively. Drug leakage past a properly inflated tourniquet ( $15 \%$ from the upper limb and $29 \%$ from the lower limb) has been reported. ${ }^{11}$

Lidocaine $0.5 \%$ ( $3 \mathrm{mg}^{\mathrm{kg}}{ }^{-1}$, average $200 \mathrm{mg}$ ) is most commonly used for IVRA. Since systemic toxicity is dose-dependent, new approaches aim to reduce the dose of lidocaine and supplement with opioid, nondepolarising muscle relaxant or nonsteroidal anti-inflammatory drugs (NSAID); this is an example of balanced analgesia. Morphine $(6 \mathrm{mg})$, meperidine $(100 \mathrm{mg})$ and fentanyl $(100-200 \mu \mathrm{g})$ have been used with local anaesthetics with varying success. Meperidine distinguishes itself from other opioids in that, when used alone, it produces IVRA ${ }^{12}$ but the optimal supplemental dose to local anaesthetic has not been established.

Low-dose nondepolarising muscle relaxants $(0.5 \mathrm{mg}$ pancuronium; $2 \mathrm{mg}$ atracurium; and $0.6 \mathrm{mg}$ mivacurium) have been used successfully to improve the onset time and intensity of motor block with IVRA. The combination of low dose $1.5 \mathrm{mg} \cdot \mathrm{kg}^{-1}$ lidocaine with $1 \mu \mathrm{g} \cdot \mathrm{kg}^{-1}$ fentanyl and $0.5 \mathrm{mg}$ pancuronium produces an anaesthetic effect similar to that of $3 \mathrm{mg} \cdot \mathrm{kg}^{-1}$ lidocaine at $20 \mathrm{~min} .{ }^{13,14}$ Only minor side effects of dizziness and diplopia are observed at the time of tourniquet deflation. It must be emphasised that muscle relaxant administration must be carefully monitored, because the systemic effect of higher doses is potentially lethal.

The addition of NSAIDs to IVRA can substantially prolong postoperative analgesia. ${ }^{15}$ Injectable ketorolac $(60 \mathrm{mg})$ added to $190 \mathrm{mg}$ lidocaine can prolong analgesia to $10 \mathrm{hr}$ (mean) and substantially reduce the need for analgesic supplementation. The mechanism of action presumably is an anti-inflammatory response at peripheral nerve endings, not a systemic effect. A similar response is seen following direct wound infiltration with ketorolac. ${ }^{16}$ Although side effects have not been reported following $60 \mathrm{mg}$ ketorolac, a reduction in dose (e.g., to $30 \mathrm{mg}$ ) might be worth exploring.

\section{Brachial plexus block}

Recently, several new approaches to brachial plexus block have been described. The mid-humeral approach blocks the brachial plexus below the axilla through a single needle puncture in the upper third of the arm by anaesthetising, individually, each of the four terminal branches (median, ulnar, radial and musculocutaneous nerves) with $10 \mathrm{ml}$ local anaesthetic. ${ }^{17}$ At first glance, this approach seems complicated but with experience, this block can be achieved with $88 \%$ success in $6 \pm 2$ min. ${ }^{18}$ Block of the musculocutaneous and radial nerves (commonly missed by the axillary approach) is more consistent, and anaesthesia and analgesia can be selectively prolonged in a specific nerve that subserves the surgical site with a long-acting local anaesthetic.

Several novel supraclavicular approaches have been described in recent years: the most recent is the intersternocleidomastoid technique. ${ }^{19}$ Briefly, a needle is advanced between the two heads (sternal and clavicular) of the sternocleidomastoid (SCM) muscle, similar to internal jugular vein catheterisation, but more laterally toward the midpoint of the clavicle. Passing behind the SCM muscle, the needle makes contact with the superior trunk of the brachial plexus, making this block more suitable for shoulder and arm surgery than for hand surgery. Advantages include easily recognisable surface landmarks, a needle insertion site farther from the dome of the lung, a high success rate (93\%), and ease of catheter placement for pain control.

To overcome the blind nature of brachial plexus block, target nerves can be localised accurately using ultrasound technology, thereby avoiding risk of vascular or pleural puncture. Also, the spread of local anaesthetic in the plexus sheath can be confirmed. The role of ultrasound in guiding needle placement remains to be defined. ${ }^{20}$

Some new information recently made available may change our clinical practice. When interscalene block is done for shoulder surgery, eliciting proximal paraesthesia at the shoulder is found to be as reliable as distal paraesthesia elicited in the forearm or hand. ${ }^{21}$ Traditionally considered unsuitable for elbow surgery, a recent study found that axillary block provided adequate surgical anaesthesia in $89 \%$ of patients undergoing various elbow operations, compared with $78 \%$ for supraclavicular block and $75 \%$ for interscalene block. ${ }^{22}$ Block success was associated with mepivacaine, epinephrine and the paraesthesia technique, and failure with transarterial injection of bupivacaine. Neither digital pressure nor arm adduction is found to influence the spread of local anaesthetic or block success of axillary block. ${ }^{23,24}$ Of the three transarterial approaches (posterior $v s$ anterior $v s$ "half and half"), the least successful for median nerve block appears to be the posterior, perhaps because the artery acts as a physical barrier to diffusion of local anaesthetic to the median nerve. ${ }^{25}$ Finally, the maximum dose of lidocaine for brachial plexus block may be higher than currently 
recommended. When $900 \mathrm{mg}$ lidocaine containing epinephrine was injected for transarterial axillary block, success was $100 \%$ while the highest mean blood level was $2.9 \mu \mathrm{g} \cdot \mathrm{ml}^{-1}$ (toxic $>5 \mu \mathrm{g} \cdot \mathrm{ml}^{-1}$ ). ${ }^{26}$ However, it is important to emphasise that if such a big dose is injected intravascularly by accident, serious toxic reactions will occur.

\section{Lower extremity block}

The use of peripheral nerve blocks for lower extremity surgery is increasing. Compared with central neuraxial blockade, peripheral nerve blocks can provide one-sided anaesthesia and lasting analgesia without the risk of haemodynamic instability, urinary retention, or back pain. Sciatic nerve block $\left(L_{4}-S_{2}\right)$ is useful for foot and ankle surgery, femoral nerve block $\left(\mathrm{L}_{2-4}\right)$ for post-arthroscopic analgesia, and combined sciatic and femoral nerve block for surgery of the entire lower extremity.

\section{Parasacral sciatic nerpe block}

Parasacral sciatic nerve block can be considered a unilateral sacral plexus block because it targets the sciatic nerve as it emerges the greater sciatic foramen in close proximity to the sacral plexus, thus blocking other branches of the plexus (including the obturator nerve) ${ }^{27,28} \mathrm{It}$ is also technically easier to place an indwelling catheter for postoperative pain treatment with this approach. ${ }^{29}$ Several new bony landmarks have been described to facilitate nerve localisation..$^{27,28}$

\section{Popliteal sciatic nerve block}

Improvements in the approach to popliteal sciatic nerve block have increased success. Needle insertion in true midline is more likely to make contact with the sciatic nerve than the classical approach (needle insertion $1 \mathrm{~cm}$ lateral to the midline of the posterior thigh). Supine posterior and lateral variations of popliteal nerve block have been described. ${ }^{30,31}$ When seeking the nerve, specific motor responses that provide reliable endpoints when using a nerve stimulator are inversion (action of deep peroneal and posterior tibial nerves) and dorsiflexion; eversion and plantar flexions are not effective. ${ }^{32}$

Because the sciatic nerve branches into the tibial and peroneal nerves at $8 \pm 3 \mathrm{~cm}$ above the popliteal crease, injection of anaesthetic $10 \mathrm{~cm}$ above the crease (classical approach) may not always block both divisions. However, a complete block can occur even when only one branch of the nerve is contacted because of an epineural sheath which surrounds the sciatic nerve and its divisions allowing cephalad and caudad spread as long as the local anaesthetic is injected within this sheath. ${ }^{33}$ This sheath also forms a conduit for indwelling catheter and local anaesthetic infusion for continuous sciatic nerve block analgesia after foot surgery. ${ }^{34}$ Also applicable for foot surgery is a new compartment block below the popliteal fossa which blocks the tibial and common peroneal nerves individually in separate osteofascial compartments. ${ }^{35}$

\section{Femoral nerve block}

Femoral nerve block combined with light general anaesthesia can substantially reduce opioid requirement following anterior cruciate ligament repair. ${ }^{36}$ However, when compared with multi-modal systemic analgesic regimen, continuous femoral nerve block does not add any benefit to patients after total knee arthroplasty. ${ }^{37}$ Femoral (3-in-1) block does not consistently anaesthetise the obturator nerve ${ }^{38}$ but success can be improved by ultrasound guided technique. ${ }^{39}$ The presence of a femoral nerve sheath for inguinal paravascular lumbar plexus block has been questioned. ${ }^{40}$

\section{Fast track recovery}

New application of peripheral nerve blocks in the lower extremity can expedite outpatient recovery. For example, blockade of the femoral and genito-femoral nerves for stripping of the long saphenous vein resulted in quicker recovery, fewer complications and lower incidence of postoperative pain than spinal anaesthesia. ${ }^{41}$ Similarly, selective blockade of the popliteal nerve and posterior cutaneous nerve of the thigh for stripping of the short saphenous vein provides satisfactory surgical anaesthesia and faster recovery. ${ }^{42}$

\section{Spinal anaesthesia}

The use of lidocaine $5 \%$ solution for spinal anaesthesia has been the centre of a neurotoxicity controversy in recent years. ${ }^{43}$ Cauda equina syndrome has been reported following a single lidocaine $5 \%$ injection. ${ }^{44}$ In in vitro animal studies, nerve immersion in lidocaine $5 \%$ led to concentration-dependent irreversible conduction block. ${ }^{45}$ Transient radicular irritation (TRI), a syndrome of back and leg pain occurring after spinal anaestheric, is common with lidocaine (16\%-37\%) but not bupivacaine. ${ }^{46-48}$ TRI is predisposed by the lithotomy position and drug maldistribution, but not affected by the presence of epinephrine, dextrose, and lowering of lidocaine concentration to $2 \%$. Recently, phenylephrine has been found to increase the potential for TRI after spinal tetracaine anaesthesia. ${ }^{49}$ Although the mechanism is unknown, many believe TRI represents a mild form of neurotoxicity. Based on these clinical and laboratory findings, spinal lidocaine 5\% solution is no longer recommended for spinal anaesthesia. However, in my opinion, lidocaine remains a useful shortacting agent, particularly for outpatient surgery. The current recommendation is to use dilute lidocaine in a concentration of $1.5 \%$ or less, not exceeding $100 \mathrm{mg}$ although some recommend $s 60 \mathrm{mg} .{ }^{50}$ 


\section{Dilute local anaesthetic}

Onset, quality and duration of spinal hyperbaric lidocaine $1.5 \%$ block are clinically indistinguishable from the $5 \%$ solution..$^{51}$ It is only in volunteer study that one can show regression of sensory and motor block is $30 \%$ more rapid with the hyperbaric $1.5 \%$ solution. ${ }^{52}$ Even a more dilute $0.5 \%$ solution is effective when given in low dose $(25-40 \mathrm{mg})$ to attain surgical anaesthesia for minor gynaecological ${ }^{53}$ perirectal ${ }^{54}$ and urological procedures. ${ }^{55}$ Interestingly, the degree of anaesthetic block is similar following $70 \mathrm{mg}$ lidocaine in concentrations ranging from $0.5 \%$ to $10 \%$ : the CSF lidocaine concentration becomes similar at $20 \mathrm{~min}$ after induction irrespective to the administered concentration as long as the dose is kept constant. ${ }^{56}$ Recently, a new concept of mean effective anaesthetic concentration (MEAC) has been described, similar to MAC for inhalational anaesthetic. ${ }^{57}$ The MEAC of hyperbaric lidocaine to produce complete sensory and motor block in $50 \%$ of human subjects was found to be $0.54 \%$ when $48 \mathrm{mg}$ were given and this value is dose dependent.

Long-acting isobaric bupivacaine has been used successfully for outpatient arthroscopy ${ }^{58}$ The recommended dose is $7.5 \mathrm{mg}$, but the resultant block does not consistently provide complete leg paralysis and the time to micturition can be long.

\section{Opioid supplement}

The addition of opioid to supplement low-dose spinal anaesthesia is also new. Combining $25 \mu \mathrm{g}$ fentanyl with $25 \mathrm{mg}$ hypobaric lidocaine provides sufficient anaesthesia for a $30-\mathrm{min}$ laparoscopic procedure and leads to quicker sensory and motor block recovery and time to reach discharge than conventional spinal lidocaine alone ${ }^{59}$ Similarly, the addition of $10 \mu \mathrm{g}$ fentanyl to bupivacaine, $5.4 \mathrm{mg}$, for outpatient arthroscopy permits the use of a low dose that would otherwise be inadequate. ${ }^{60}$

Traditionally, low-dose fentanyl, 20-25 $\mu \mathrm{g}$, is added to a conventional dose of local anaesthetic in order to prolong analgesia in the immediate postoperative period. ${ }^{61}$ This does not affect the duration of motor block but can increase the incidence of hypotension and pruritus. It is important to note that, although rare, respiratory arrest following intrathecal fentanyl, ${ }^{62} 20 \mu \mathrm{g}$, or $10 \mu \mathrm{g}$ sufentanil has been reported. ${ }^{63}$

\section{Combined spinal epidural anaesthesia}

This combined spinal epidural technique (CSE) offers tremendous flexibility - the initially placed spinal block produces rapid onset of anaesthesia and subsequent epidural block offers the route to supplement anaesthesia during surgery as needed and to provide postoperative analgesia. ${ }^{64}$ To lower the risk of hypotension, a relatively small subarachnoid dose of local anaesthetic (e.g., $30-40 \mathrm{mg}$ lidocaine) is given initially. The combination has been used successfully to reduce side effects and time to discharge for outpatient knee arthroscopy. ${ }^{65}$ These advantages make this technique appropriate for Caesarean delivery, labour pain and outpatient lower limb surgery.

\section{Epidural top-ups}

Epidural injection of $15 \mu \mathrm{g}$ epinephrine after the induction of spinal anaesthesia remains a reliable test dose. ${ }^{66}$ Extension of subarachnoid block is rapid after epidural drug injection. Mechanisms of action for this effect include: 1) rapid transfer of local anaesthetic through the punctured hole in the dura mater, 2) the existence of subclinical analgesia being brought to full analgesic strength by small local anaesthetic increments, and 3 ) a cephalad shift of local anaesthetic within the CSF caused by compression of the dural sac by the epidurally injected volume. However, the impact of volume on cephalad shift depends on the timing of epidural reinforcement. If epidural top-up is given five minutes after subarachnoid injection, the final maximum block level is the same with $10 \mathrm{ml}$ of saline or bupivacaine, ${ }^{67}$ if topup occurs 15-20 min after subarachnoid injection, the same dose of epidural bupivacine will produce a final block that is three dermatomal segments higher than that produced by saline which, in turn, is two segments greater than no injection at all. ${ }^{68}$ During regression of spinal anaesthesia, only epidural lidocaine prolongs sensory and motor block; epidural saline injection can shorten the duration of sensory block. ${ }^{69}$

\section{Risks}

Reports of cardiorespiratory arrest following epidural opioid administration during CSE for Caesarean section have raised speculation that significant amount of epidural opioid can spread transdurally through the dural hole. ${ }^{70}$ Studies to date demonstrate that the rate of flux is dependent on the size of the hole and not on physicochemical properties of the drugs administered. For example, there is no significant drug movement through a small dural puncture made by a 24 or 26 gauge needle. $^{71,72}$ The situation is different when puncture is caused by an 18 gauge Tuohy needle "wet-tap." 72 Risk of catheter penetration through a dural hole is also very remote unless the dura is punctured by 22-gauge or larger needle as shown in an epiduroscopic study. ${ }^{73}$

\section{Combined epidural and general anaesthesia}

This balanced approach is used with increasing popularity for major thoracic, abdominal and vascular surgery. To use this technique effectively and safely 
requires rigorous attention to epidural placement, test dose administration, and choice of top-up agents.

\section{Thoracic epidural technique}

The practice of thoracic epidural anaesthesia is growing in North America but well-established elsewhere. Ideally, the epidural catheter should be placed as close as possible to the site of pain in the appropriate dermatome; for example, a $\mathrm{T}_{5-7}$ catheter is placed for thoracotomy and a $T_{9.12}$ catheter for an abdominal incision especially when local anaesthetic and/or lipid-soluble opioid agents are used. Technical difficulty and potential spinal cord injury are two major concerns but the safety of thoracic epidural catheterisation is well-documented. ${ }^{74}$ The incidence of major or minor complications is low, comparable to that with lumbar catheterisation.

\section{Epidural test dose}

The common epidural test dose contains $\mathbf{4 5} \mathrm{mg}$ lidocaine and $15 \mu \mathrm{g}$ epinephrine. In the awake patient, haemodynamic changes after $i v$ injection manifest as an increase in heart rate and systolic blood pressure of $20 \mathrm{bpm}$ and $15 \mathrm{mmHg}$, respectively. Ideally, epidural test dose is given before induction of general anaesthesia. However, if it is given in the anaesthetised patient, the test dose response is blunted because volatile anaesthetics induce dose-dependent depression of cardiovascular function. ${ }^{75,76} \mathrm{~A}$ new set of positive response criteria has been suggested: an increase of heart rate $>8 \mathrm{bpm}$ and systolic blood pressure $>13$ $\mathrm{mmHg}$ occurring $60 \mathrm{sec}$ and $120 \mathrm{sec}$, respectively, after injection. ${ }^{76}$ However, these criteria reflect only healthy, young subjects receiving isoflurane and nitrous oxide anaesthesia; haemodynamic parameters for sick or elderly patients undergoing different regimes are not yet established. Isoproterenol, $2 \mu \mathrm{g}$, is also a useful marker for iv injection, but the neurotoxic potential of this drug has not been tested. ${ }^{77}$

\section{Top-ups}

Haemodynamic stability during general anaesthesia can be preserved by using less local anaesthetic and more opioid for epidural analgesia. Options include boluses of fast-acting epidural opioids such as fentanyl; use a continuous infusion of dilute local anaesthetic (e.g, bupivacaine $0.1 \%$ ) with opioid (e.g., $0.05 \mathrm{mg} \cdot \mathrm{ml}^{-1}$ morphine or $4 \mu \mathrm{g} \cdot \mathrm{ml}^{-1}$ fentanyl). During isoflurane anaesthesia, hypotension is more likely to occur with bolus administration of epidural lidocaine than epidural fentanyl. ${ }^{78}$ Epidural fentanyl also attenuates hypertensive and cough responses to tracheal extubation at the time of emergence. ${ }^{79}$

\section{Postoperative epidural analgesia}

The clinical benefits of postoperative epidural analgesia for patient outcome are well-documented. ${ }^{80}$ Epidural analgesia is superior to systemic analgesia for controlling pain at rest, and especially during movement and coughing. Several, ${ }^{81,82}$ but not all, ${ }^{83,84}$ studies report improved cardiac and pulmonary function following major vascular, thoracic or abdominal surgery.

\section{Gastrointestinal benefits}

There is growing interest in the effect of epidural analgesia on enhancing postoperative gastrointestinal motility ${ }^{85}$ Following major abdominal procedures, paralytic ileus delays enteral diet resumption at an estimated in-hospital cost of at least $\$ 750$ million annually. Many studies have shown that local anaesthetic can speed intestinal recovery ${ }^{86}$ but systemic and epidural opioids may impair motility and worsen paralytic ileus. When used alone to achieve analgesia, local anaesthetic imposes risk of leg paralysis and orthostatic hypotension. But when used in combination, low dose bupivacaine-morphine infusion was found to speed recovery by as much as 1.5 days. ${ }^{86}$ For optimal benefit, epidural therapy should be continued for at least $48 \mathrm{hr}$ until ileus resolution. Other factors contributing to GI recovery include early enteral feeding, patient ambulation, and the use of systemic ketorolac.

\section{Epidural opioids}

The opioids commonly used for epidural analgesia have recently been reviewed. ${ }^{87}$ Although the lipidsoluble fentanyl lacks the epidural efficacy of morphine, it reduces risk of respiratory depression. To optimise the spinally mediated effect, the epidural site of injection should be close to the dermatome corresponding to the surgical site (e.g., thoracic injection for thoracotomy incision). With used alone in high doses (e.g., $80 \mathrm{mg} \cdot \mathrm{hr}^{-1}$ ), analgesia, side effects and plasma concentration are comparable to those of $i v$ fentanyl, suggesting significant systemic absorption. Spinally mediated analgesia is evident when fentanyl is administered in low concentration $\left(4-6 \mu \mathrm{g} \cdot \mathrm{ml}^{-1}\right)$ and in combination with a subanalgesic dose of bupivacaine $0.1 \%$ local anaesthetic to demonstrate enhanced analgesia. ${ }^{88}$ Sufentanil also produces analgesia via both spinal and systemic effects.

\section{Patient-controlled epidural analgesia}

Patient-controlled epidural analgesia (PCEA) is a relatively new delivery method that provides analgesia equivalent to that of physician-controlled continuous epidural infusion but at reduced dosage and potentially 
with fewer side effects. ${ }^{89}$ Patients have increased satisfaction, in part, due to having a sense of "control" and the flexibility to increase analgesic demand to match pain during movement. A variety of opioids are effective, often given in bolus-only modality. ${ }^{90,91}$ However, I believe it prudent to establish PCEA as a basal infusion, with bolus supplementation and to reduce the dosage of both to match the decreasing need for analgesia as pain decreases. At our institution, we use two epidural solution mixtures containing bupivacaine $0.1 \%$ and $4 \mu \mathrm{g} \cdot \mathrm{ml}^{-1}$ fentanyl or $0.03 \mathrm{mg} \cdot \mathrm{ml}^{-1}$ hydromorphone, and a starting infusion rate of $4-8 \mathrm{ml} \cdot \mathrm{hr}^{-1}$ adjusted for site of administration (lower for thoracic catheters). The PCA dose is usually $30 \%$ of the hourly basal infusion rate; the lockout interval is $15-30 \mathrm{~min}$.

\section{Summary}

Advances in regional anaesthesia to date have made it one of the safest modalities for surgical anaesthesia and pain management. Continued refinement and development of new block techniques and approaches enhance the potential for block success, rapid postoperative recovery and patient safety. This will benefit both patient care and the health care economy.

\section{References}

1 Auroy $\Upsilon$, Narchi P, Messiab A, Litt L, Rouvier B, Sammii K Serious complications related to regional anaesthesia. Results of a prospective survey in France. Anesthesiology 1997; 87: 479-86.

2 Scott DB, Lee A, Fagan D, Bowler GMR, Bloomfield P, $L u n d h R$. Acute toxicity of ropivacaine compared with that of bupivacaine. Anesth Analg 1989; 69: 563-9.

3 Korman B, Riley RH. Convulsions induced by ropivacaine during interscalene brachial plexus block. Anesth Analg 1997; 85: 1128-9.

$4 \mathrm{McClure}$ JH. Ropivacaine. A review article. Br J Anacsth 1996; 76: 300-7.

5 Finucane BT, Sandler AN, McKenna J, et al. A doubleblind comparison of ropivacaine $0.5 \%, 0.75 \%, 1.0 \%$, and bupivacaine $0.5 \%$, injected epidurally, in patients undergoing abdominal hysterectomy. Can J Anaesth 1996; 43: 442-9.

6 van Kleef JW, Veering BTh, Burm AGL. Spiną anesthesia with ropivacaine: a doubleblind study on the efficacy and safety of $0.5 \%$ and $0.75 \%$ solutions in patients undergoing minor lower limb surgery. Anesth Analg 1994; 78: 1125-30.

7 Schug SA, Scott DA, Payne J, Mooney PH, Hagglof B. Postoperative analgesia by continuous extradural infusion of ropivacaine after upper abdominal surgery. Br J Anaesth 1996; 76: 487-91.
8 Erichsen C-J, Sjovall J, Keblet H, Hedlund C, Arvidsson T. Pharmacokinetics and analgesic effect of ropivacaine during continuous epidural infusion for postoperative pain relief. Anesthesiology 1996; 84: 834-42.

9 Etches RC, Writer WDR, Ansley D, et al. Continuous epidural ropivacaine $0.2 \%$ for analgesia after lower abdominal surgery. Anesth Analg 1997; 84: 784-90.

10 Henderson $C L$, Warriner CB, McEwen JA, Merrick PM. A North American survey of intravenous regional anesthesia. Anesth Analg 1997; 85: 858-63.

11 Hoffmann $A C$, van Gessel E, Gamulin $Z$ Ryser JE, Forster $A$. Quantitative evaluation of tourniquet leak during iv regional anaesthesia of the upper and lower limbs in human volunteers. Br J Anaesth 1995; 75: 269-73.

12 Acalovschi $I$, Cristea $T$. Intravenous regional anacsthesia with meperidine. Anesth Analg 1995; 81: 539-43.

13 Sztark $F$, Thicoipe $M$, Favarel-Garrigues JF, Lassie $P$, Petitjean ME, Dabadie P. The use of $0.25 \%$ lidocaine with fentanyl and pancuronium for intravenous regional anesthesia. Anesth Analg 1997; 84: 777-79.

14 Abdulla Wr, Fadhil NM. A new approach to intravenous regional anesthesia. Anesth Analg 1992; 75: 597-601.

15 Reuben SS, Steinberg RB, Kreitzer JM, Duprat KM. Intravenous regional anesthesia using lidocaine and ketorolac. Anesth Analg 1995; 81: 110-3.

16 Reuben SS, Duprat KM. Comparison of wound infiltration with ketorolac versus intravenous regional anesthesia with ketorolac for postoperative analgesia following ambulatory hand surgery. Reg Anesth 1996; 21: 565-8.

17 Dupre L-J. Bloc du plexus brachial au canal humeral. Cahiers d'Anesthesiologic 1994; 42: 767-9.

18 Bouaziz H, Narchi P, Mercier FJ, et al. Comparison between conventional axillary block and a new approach at the midhumeral level. Anesth Analg 1997; 84: 1058-62.

19 Pham Dang C, Gunst J-P, Gouin F, et al. A novel supraclavicular approach to brachial plexus block. Anesth Analg 1997; 85: 111-6.

20 Kapral S, Kraffl P, Eibenberger K, Fitzgerald R, Gosch $M$, Weinstabl $C$. Ultrasoundguided supraclavicular approach for regional anesthesia of the brachial plexus. Anesth Analg 1994; 78: 507-13.

21 Urban $M K$, Urquhart B. Evaluation of brachial plexus anesthesia for upper extremity surgery. Reg Anesth 1994; 19: 175-82.

22 Schroeder LE, Horlocker TT, Schroeder DR. The efficacy of axillary block for surgical procedures about the elbow. Anesth Analg 1996; 83: 747-51.

23 Koscielniak-Nielsen ZJ, Horn A, Rotboll Nielsen P. Effect of arm position on the effectiveness of perivascu- 
lar axillary nerve block. $\mathrm{Br} \mathrm{J}$ Anaesth 1995; 74: 387-91.

24 Koscielniak-Nielsen ZJ, Christiensen LQ Pedersen HLS, Brushoj J. Effect of digital pressure on the neurovascular sheath during perivascular axillary block. Br J. Anaesth 1995; 75: 702-6.

25 Hickey R, Rogers JN, Hoffman J, Ramamurthy S, Tingle LJ. Comparison of the clinical efficacy of the three perivascular techniques for axillary brachial plexus block. Reg Anesth 1993; 18: 335-8.

26 Palve H, Kirvela O, Syvalabti E, Kanto J. Maximum recommended doses of lignocaine are not toxic. Br J Anaesth 1995; 74: 704-5.

27 Chang PC, Lang SA, Yip $R W$. Reevaluation of the sciatic nerve block. Reg Anesth 1993; 18: 18-23.

28 Mansour Nr. Reevaluating the sciatic nerve block: another landmark for consideration (Letter). Reg Anesth 1993; 18: 322-3.

29 Morris GF, Lang $S A$. Continuous parasacral sciatic nerve block: two case reports. Reg Anesth 1997; 22: 469-72.

30 Vloka JD, Hadzic A, Koorn R, Thys D. Clinical reports. Supine approach to the sciatic nerve in the popliteal fossa. Can J Anaesth 1996; 43: 964-7.

31 McLeod DH, Wong DHW, Vaghadia $H$, Claridge RJ, Merrick PM. Lateral popliteal sciatic nerve block compared with ankle block for analgesia following foot surgery. Can J Anaesth 1995; 42: 765-9.

32 Benzon HT, Kim C, Benzon HP, et al. Correlation between evoked motor response of the sciatic nerve and sensory blockade. Anesthesiology 1997; 87: 547-52.

33 Vloka JD, Hadzic A, Lesser JB, et al. A common epineurial sheath for the nerves in the popliteal fossa and its possible implications for sciatic nerve block. Anesth Analg 1997; 84: 387-90.

34 Singelyn FJ, Aye F, Gouverneur JM. Continuous popliteal sciatic nerve block: an original technique to provide postoperative analgesia after foot surgery. Anesth Analg 1997; 84: 383-6.

35 Mansour NY Compartment block for foot surgery. A new approach to tibial nerve and common peroneal nerve block. Reg Anesth 1995; 20: 95-9.

36 Edkin BS, Spindler KP, Flanagan JFK. Femoral nerve block as an alternative to parenteral narcotics for pain control after anterior cruciate ligament reconstruction. Arthroscopy: The Journal of Arthroscopic and Related Surgery 1995; 11: 404-9.

37 Ganapathy S, Moote C, Wassermann R, Watson J, Armstrong. Efficacy of continuous femoral block following total knee arthroplasty. Can J Anaesth 1997; 44: A68.

38 Marbofer $P$, Schrogendorfer $K$, Koinig $H$, Kapral S, Weinstabl $C$, Mayer $N$. Ultrasonographic guidance improves sensory block and onset time of three-in-one blocks. Anesth Analg 1997;85: 854-7.

39 Atanassoff $P G$, Weiss $B M$, Brull SJ, et. al. Electromyographic comparison of obturator nerve block to three-in-one block. Anesth Analg 1995; 81: 529-33.

40 Ritter JW. Femoral nerve "sheath" for inguinal paravascular lumbar plexus block is not found in human cadavers. J Clin Anesth 1995; 6: 470-3.

41 Vloka JD, Hadzic A, Mulcare $R$, Lesser JB, Kitain E, Thys DM. Femoral and genitofemoral nerve blocks versus spinal anesthesia for outpatients undergoing long saphenous vein stripping surgery. Anesth Analg 1997; 84: 749-52.

42 Vloka JD, Hadzic A, Mulcare $R$, Lesser JB, Koorn $R$, Thys DM. Combined popliteal and posterior cutenous nerve of the thigh blocks for short saphenous vein stripping in outpatients: an alternative to spinal anesthesia. J Clin Anesth 1997; 9: ???-???

43 Carpenter $R L$. Hyperbaric lidocaine spinal anesthesia: do we need the alternative? Anesth Analg 1995; 81 : 1125-8.

44 Gerancher J. Cauda equina syndrome following a single spinal administration of $5 \%$ hyperbaric lidocaine through a 25-gauge whitacre needle. Anesthesiology $1997 ; 87: 687-9$.

45 Bainton CR, Strichartz GR. Concentration dependence of lidocaine-induced irreversible conduction loss in frog nerve. Anesthesiology 1994; 81: 657-67.

46 Hampl KF, Schneider MC, Ummenhofer $W$, Drewe J. Transient neurologic symptoms after spinal anesthesia. Anesth Analg 1995; 81: 1148-53.

47 Pollock JE, Neal JM, Stephenson CA, Wiley CE. Prospective study of the incidence of transient radicular irritation in patients undergoing spinal anesthesia. Anesthesiology 1996; 84: 1361-7.

48 Tarkkila $P$, Hubtala J, TuominenM. Transient radicular irritation after spinal anaesthesia with hyperbaric $5 \%$ lignocaine. Br J Anaesth 1995; 74: 328-9.

49 Sakura S, Sumi M, Sakqguchi $\Upsilon$, Saito $Y$, Kosaka $\Upsilon$, Drasner $K$ The addition of phenylephrine contributes to the development of transient neurologic symptoms after spinal anaesthesia with $0.5 \%$ tetracaine. Anesthesiology 1997; 87: 771-8.

50 Drasner $K$. Lidocaine spinal anaesthesia. A vanishing therapeutic index? Anesthesiology 1997; 87: 469-71.

51 Markey $J R$, Montiague $R$, Winnie AP. A comparative efficacy study of hyperbaric $5 \%$ lidocaine and $1.5 \%$ lidocaine for spinal anesthesia. Anesth Analg 1997; 85: 1105-7.

52 Liu S, Pollock JE, Mulroy MF, Allen HW, Neal JM, Carpenter RL. Comparison of $5 \%$ with dextrose, $1.5 \%$ with dextrose, and $1.5 \%$ dextrose-free lidocaine solutions for spinal anesthesia in human volunteers. Anesth Analg 1995; 81: 697-702. 
53 Liew QY, Tay DHB, Thomas E. Lignocaine 0.5\% for spinal anaesthesia in gynaecological day surgery. Anaesthesia 1994; 49: 633-6.

54 Bodily $M N$, Carpenter $R L$, Owens $B D$. Lidocaine $0.5 \%$ spinal anaesthesia: a hypobaric solution for short-stay perirectal surgery. Can J Anaesth 1992; 39: 770-3.

55 Chan VWS, Garcia J, AI-Kaisy A, Drasner $K$. A comparative study of low dose hyperbaric spinal lidocaine $0.5 \%$ versus $5 \%$ for continuous spinal anesthesia. Reg Anesth 1998 (in press).

56 Van Zundert AAJ, Grouls RJE, Korsten HHM, Lambert DH. Spinal anesthesia. Volume or concentration What matters? Reg Anesth 1996; 21: 112-8.

57 Peng PWH, Chan VWS, Perlas A. Minimum effective anaesthetic concentration of hyperbaric lidocaine for spinal anaesthesia. Can J Anaesth 1998; 45 : (in press).

58 Ben-David B, Levin $H$, Solomon E, Admoni $H$, Vaida $S$. Spinal bupivacaine in ambulatory surgery: the effect of saline dilution. Anesth Analg 1996; 83: 716-20.

59 Vaghadia $H$, McLeod DM, Mitchell GWE, Merrick PM, Chilvers $C R$. Small-dose hypobaric lidocaine-fentanyl spinal anesthesia for short duration outpatient laparoscopy. I. A randomized comparison with conventional dose hyperbaric lidocaine. Anesth Analg 1997; 84: 59-64.

60 Ben-David B, Solomon E, Levin H, Admoni $H$, Goldik $Z$. Intrathecal fentanyl with small-dose dilute bupivacaine: better anesthesia without prolonging recovery. Anesth Analg 1997; 85: 560-5.

61 Liu $S$, Chiu AA, Carpenter $R L$, et al. Fentanyl prolongs lidocaine spinal anesthesia without prolonging recovery. Anesth Analg 1995; 80: 730-4.

62 Cornish PB. Respiratory arrest after spinal anesthesia with lidocaine and fentanyl. Anesth Analg 1997; 84: 1387-8.

63 Ferouz $F$, Norris $M C$, Leighton $B L$. Risk of respiratory arrest after intrathecal sufentanil. Anesth Analg 1997; 85: 1088-90.

64 Rawal N, Van Zundert A, Holmstrom B, Crowhurst JA. Combined spinal-epidural technique. Reg Anesth 1997; 22: 406-23.

65 Urmey WF, Stanton J, Peterson $M$, Sharrock NE. Combined spinal-epidural anesthesia for outpatient surgery. Dose-response characteristics of intrathecal isobaric lidocaine using a 27-gauge whitacre spinal needie. Anesthesiology 1995; 83: 528-34.

66 Liu SS, Stevens $R A$, Vasquez J, et al. The efficacy of epinephrine test doses during spinal anesthesia in volunteers: implications for combined spinal-epidural anesthesia. Anesth Analg 1997; 84: 780-3.

67 Blumgart CH, Ryall D, Dennison B, Thompson-Hill LM. Mechanism of extension of spinal anaesthesia by extradural injection of local anaesthetic. $\mathrm{Br} \mathrm{J}$ Anaesth 1992; 69: 457-60.
68 Stienstra R, Dahan A, Albadi BZR, van Kleef JW, $B u r m$ AGL. Mechanism of action of epidural an top-up in combined spinal epidural anesthesia. Anesth Analg 1996; 83: 382-6.

69 Trautman WJ, Liu SS, Kopacz DJ. Comparison of lidocaine, and saline for epidural top-up during combined spinal-epidural anesthesia in volunteers. Anesth Analg 1997; 84: 574-7.

70 Eldor J, Guedj P, Levine S. Delayed respiratory arrest in combined spinal-epidural anesthesia. Reg Anesth 1994; 19: 418-22.

71 Suzuki N, Koganemaru M, Onizuka S, Takasaki M. Dural puncture with a 26-gauge spinal needle affects spread of epidural anesthesia. Anesth Analg 1996; 82: 1040-2.

72 Bernards CM, Kopacz DJ, Michel MZ. Effect of needle puncture on morphine and lidocaine flux through the spinal meninges of the monkey in vitro. Implications for combined spinal-epidural anesthesia.

Anesthesiology 1994; 80: 853-8.

73 Holmstrom $B$, Rawal $N$, Axelsson $K$, Nydabl PA. Risk of catheter migration during combined spinal epidural block: percutaneous epiduroscopy study. Anesth Analg 1995; 80: 747-53.

74 Giebler $R M$, Scherer $R U$, Peters J. Incidence of neurologic complications related to thoracic epidural catheterization. Anesthesiology 1997; 86: 55-63.

75 Tanaka M, Takabashi S, Kondo T, Matsumiya $N$. Efficacy of simulated epidural test doses in adult patients anesthetized with isoflurane: a dose-response study. Anesth Analg 1995; 81: 987-92.

76 Liu SS, Carpenter RL. Hemodynamic responses to intravascular injection of epinephrine-containing epidural test doses in adults during general anesthesia. Anesthesiology 1996; 84: 81-7.

77 Tanaka M. Simulation of an epidural test dose with intravenous isoproterenol in isoflurane-anesthetized adults. Anesth AnaIg 1997; 85: 639-43.

78 Harukuni I, ramagucbi $H$, Sato S, Naito $H$. The comparison of epidural fentanyl, epidural lidocaine, intravenous fentanyl in patients undergoing gastrectomy. Anesth Analg 1995; 81: 1169-74.

79 Inagaki $Y$, Shindo $H$, Mashimo $T$, Yoshiya $I$. The effects of epidural fentanyl on hemodynamic responses during emergence from isoflurane, anesthesia and tracheal extubation: a comparison with intravenous fentanyl. Anesth Analg 1997; 85: 328-35.

80 Liu $S$, Carpenter $R L$, Neal JM. Epidural anesthesia and analgesia. Their role in the postoperative outcome. Anesthesiology 1995; 82: 1474-506.

81 Tuman KJ, McCartby RJ, March RJ, DeLaria GA, Patel RV, Ivankovich $A D$. Effects of epidural anaesthesia and analgesia on coagulation and outcome after major vascular surgery. Anesth Analg 1991; 73: 696-704. 
82 de Leon-Casasola OA, Lema MJ, Karabella D, Harrison $P$. Postoperative myocardial ischemia: epidural versus intravenous patient-controlled analgesia. Reg Anesth 1995; 20: 105-12.

83 Jayr C, Thomas H, Rey A, Farbat F, Lasser $P$, Bourgain J-L. Postoperative pulmonary complications. Epidural analgesia using bupivacaine and opioids versus parenteral opioids. Anesthesiology 1993; 78 : 666-76.

84 Guinard JP, Mavrocordatos $P$, Chiolero $R$, Carpenter $R L$. A randomized comparison of intravenous versus lumbar and thoracic epidural fentanyl for analgesia after thoracotomy. Anesthesiology 1992; 77 : 1108-15.

85 Carpenter $R L$. Gastrointestinal benefits of regional anesthesia/analgesia. Reg Anesth 1996; 21(6S): 13-7.

86 Liu SS, Carpenter RL, Mackey DC, et al. Effects of perioperative analgesic technique on rate of recovery after colon surgery. Anesthesiology 1995; 83: 757-65.

87 de Leon-Casasola $O A$, Lema MJ. Postoperative epidural opioid analgesia: what are the choices? Anesth Analg 1996; 83: 867-75.

88 Scott DA, Beilby DSN, McClymont C. Postoperative analgesia using epidural infusions of fentanyl with bupivacaine. A prospective analysis of 1,014 patients. Anesthesiology 1995; 83: 727-37.

89 Mulroy MF. Epidural opioid delivery methods: bolus, continuous infusion, and patient-controlled epidural anesthesia. Reg Anesth 1996; 21(6S): 100-5.

90 Cooper DW, Turner $G$. Patient-controlled extradural analgesia to compare bupivacaine, fentanyl and bupivacaine with fentanyl in the treatment of postoperative pain. Br J Anaesth 1993; 70: 503-7.

91 Etches $R C$, Gammer T-L, Cornish R. Patient-controlled epidural analgesia after thoracotomy: a comparison of meperidine with and without bupivacaine. Anesth Analg 1996; 83: 81-6. 


\section{Progrès en anesthésie régionale et en traitement de la douleur}

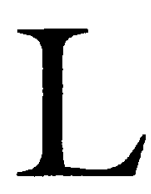

'ANESTHÉSIE régionale utilisée pour la chirurgie et le traitement de la douleur postopératoire est très sécuritaire et a connu un regain de popularité au cours des années récentes. Un nouvel anesthésique local a été mis au point et vient d'être introduit au Canada. Des techniques de bloc se sont raffinées ou ont été mises au point pour localiser plus précisément les nerfs visés. Les connaissances cliniques progressent constamment, améliorant à la fois l'efficacité des blocs et la sécurité des patients. Plus que jamais auparavant, l'anesthésie régionale fait partie d'une approche multimodale face au traitement de la douleur périopératoire et contribue à une récupération et à un congé plus rapides du patient. Cette conférence va s'attarder de façon sélective sur quelques uns des nouveaux développements importants des cinq dernières années qui ont une signification clinique pour la population adulte non obstétricale.

\section{Ropivacaïne}

La ropivacaïne (Naropin ${ }^{\circledR}$, Astra Canada), un nouvel anesthésique local de type aminoamide, a fait ses débuts au Canada en 1997. Il s'agit du premier anesthésique local préparé d'une manière isomériquement pure, car il ne contient que l'énantiomère- $S$, ce qui le rend moins toxique que la bupivacaïne qui est un mélange racémique contenant les deux énantiomères.

\section{Toxicité}

Les deux médicaments ont des profils physique et chimique analogues mais leurs effets cardiovasculaires et au niveau du système nerveux central (SNC) diffèrent. La ropivacaïne devrait déprimer moins la contractilité myocardique et la conduction et devrait provoquer moins d'arrythmies ventriculaires. La dose cardiotoxique fatale chez le mouton s'exprime par le rapport 1:2:9 pour les agents suivants bupivacaïne:ropivacaïne:lidocaïne. Une étude de toxicité du SNC a montré que des sujets humains peuvent tolérer en infusion lente $30 \%$ de plus de ropivacaïne que de bupivacaïne avant l'apparition de symptômes (moyenne $124 \mathrm{mg}$ vs $99 \mathrm{mg}$ ). On a rapporté un cas de convulsions et d'hypotension à la suite de l'injection accidentelle de $150 \mathrm{mg}$ de ropivacaïne par voie artérielle mais sans arythmie et sans séquelles. On n'a pas
Vincent Chan MD FRCPC

encore documenté la concentration sanguine toxique de ropivacaïne chez l'humain.

\section{Anesthésie}

La ropivacaïne a été utilisée pour l'anesthésie dans une variété de procédures chirurgicales et la dose maximale recommandée est de $2,5-3,0 \mathrm{mg} \cdot \mathrm{kg}^{-1}$ pour les blocs périphériques, les blocs brachiaux et les péridurales. Lorsqu'utilisé pour les blocs brachiaux, la ropivacaïne $0,5 \%$ et la bupivacaïne fournissent la même qualité de bloc sensitif et moteur avec un délai d'installation analogue, une longue durée et une excellente analgésie. Cependant, lorsque la ropivacaïne est comparée à la bupivacaïne pour l'anesthésie péridurale, il faut utiliser des concentrations plus élevées $(0,75-1,0 \%)$ et des quantités plus grandes de ropivacaïne pour obtenir un bloc moteur de la même intensité et de la même durée. Il est important de noter que la marge de sécurité de la ropivacaïne devient plus étroite si la dose est augmentée substantiellement pour accroître l'intensité du bloc moteur. L'addition d'adrénaline à la ropivacaïne n'est pas justifiée parce qu'elle ne modifie ni la durée ni l'intensité du bloc. La ropivacaïne n'est pas encore approuvée pour utilisation sous arachnoïdienne et de ce fait l'expérience avec cette utilisation est forcément limitée.

\section{Analgésie}

La propriété de séparation sensori-motrice plus grande de la ropivacaïne par voie péridurale en fait un médicament intéressant pour le traitement de la douleur postopératoire. À date, les études concernant la ropivacaïne péridurale pour l'analgésie postopératoire n'ont évalué que l'efficacité de la ropivacaïne seule en infusion aux concentrations de $0,1 \%, 0,2 \%$ et $0,3 \%$. L'efficacité analgésique s'est avérée dépendante de la dose, mais même avec $0,3 \%$ à $10 \mathrm{ml} \cdot \mathrm{h}^{-1}$ un supplément d'opiacés systémiques était nécessaire pour obtenir une analgésie adéquate. L'accumulation systémique suite à une infusion d'une durée de 24 heures à une vitesse de 10 à $30 \mathrm{ml} \cdot \mathrm{h}^{-1}$ a produit des concentrations plasmatiques basses et aucune toxicité. Cependant, même aux concentrations les plus faibles on a retrouvé des blocs moteurs se développant avec le temps. Donc, la perfusion péridurale de ropivacaïne seule n'est pas une technique utile de traitement postopéra- 
toire. Par ailleurs, la ropivacaïne à $0,1 \%$ associée à un opiacé pourrait produire une analgésie adéquate avec un risque réduit de bloc moteur mais les résultats des études restent à venir. Actuellement, la solution à $0,2 \%$ est disponible commercialement sous forme de sac pour perfusion péridurale appelé Polybag ${ }^{\oplus}$ en formats de $100 \mathrm{ml}$ et de $200 \mathrm{ml}$.

\section{Anesthésie régionale intraveineuse}

On utilise de nouvelles techniques d'anesthésie régionale intraveineuse (ARIV) pour l'anesthésie du membre supérieur pour améliorer la sécurité du patient et l'analgésie postopératoire. Une enquête récente auprès des anesthésistes nord-américains a révélé que $66 \%$ des répondants avaient rencontré des effets secondaires mineurs liés aux anesthésiques locaux chez les patients ayant subi un ARIV, alors que $14 \%$ faisaient état de convulsions et $1,2 \%$ d'arrêt cardiaque. Les complications toxiques systémiques peuvent se produire suite à des fuites importantes d'anesthésique local lorsque le garrot est gonflé, ou suite à une relâche importante lorsque le garrot est dégonflé. La fuite de médicament malgré un garrot correctement gonflé a été rapportée ( $15 \%$ au niveau du membre supérieur et $29 \%$ au niveau du membre inférieur).

La lidocaîne à $0,5 \%\left(3 \mathrm{mg} \cdot \mathrm{kg}^{-1}\right.$, moyenne $\left.200 \mathrm{mg}\right)$ est l'anesthésique le plus utilisé pour l'ARIV. Puisque la toxicité systémique dépend de la dose, de nouvelles approches visent à réduire la dose de lidocaïne par une supplémentation avec un opiacé, un relaxant musculaire non-dépolarisant ou un anti-inflammatoire non stéroïdien (AINS); ceci représente une forme d'analgésie balancée. La morphine $6 \mathrm{mg}$, la mépéridine $100 \mathrm{mg}$ et le fentanyl à raison de 100-200 $\mu \mathrm{g}$ ont été associés aux anesthésiqués locaux avec des succès variables. La mépéridine se distingue des autres opiacés en raison de ses propriétés anesthésiques propres mais la dose optimale à utiliser comme adjuvant à un anesthésique local n'a pas été établie.

Des relaxants musculaires non-dépolarisants utilisés à doses faibles (pancuronium $0,5 \mathrm{mg}$, atracurium $2 \mathrm{mg}$ ou mivacurium $0,6 \mathrm{mg}$ ) ont été utilisés avec succès pour améliorer le délai d'installation et la qualité du bloc moteur de l'ARIV. La combinaison d'une dose faible de lidocaïne $\left(1,5 \mathrm{mg} \cdot \mathrm{kg}^{-1}\right)$ avec du fentanyl $1 \mu \mathrm{g} \cdot \mathrm{kg}^{-1}$ et du pancuronium $0,5 \mathrm{mg}$ produit au bout de 20 minutes un effet analogue à celui de $3 \mathrm{mg} \cdot \mathrm{kg}^{-1}$ de lidocaïne. Au moment du dégonflement du garrot on n'observe que des effets secondaires mineurs sous forme d'étourdissements et de vision double. Il faut souligner que l'administration de relaxant musculaire doit être monitorée soigneusement parce que l'administration de doses plus élevées est potentiellement fatale.
L'addition d'AINS à l'ARIV peut prolonger l'analgésie postopératoire de façon substantielle. Du kétorolac injectable à raison de $60 \mathrm{mg}$ ajouté à $190 \mathrm{mg}$ de lidocaïne peut prolonger l'analgésie jusqu'à 10 heures en moyenne et réduire de façon substantielle les besoins de suppléments analgésiques. Le mécanisme d'action est peut-être une réponse anti-inflammatoire au niveau des terminaisons nerveuses périphériques mais ne semble pas être un effet systémique. Une réponse semblable est notée suite à une infiltration directe de la plaie avec le kétorolac. Même si on n'a pas rapporté d'effet secondaires suite à une dose de $60 \mathrm{mg}$ de kétorolac, il est probablement intéressant d'évaluer l'effet d'une dose réduite, par exemple $30 \mathrm{mg}$.

\section{Le bloc brachial}

Récemment, plusieurs nouvelles approches du bloc brachial ont été décrites. L'approche mi-bumérale bloque le plexus brachial plus bas que l'aisselle via une seule ponction au niveau du tiers supérieur du bras en anesthésiant individuellement chacune des quatre branches terminales (médian, cubital, radial, musculocutané) avec $10 \mathrm{ml}$ d'anesthésique local. À premier abord, cette approche semble compliquée, mais avec l'expérience ce bloc peut être réussi avec $88 \%$ de succès en $6 \pm$ $2 \mathrm{~min}$. Le bloc du musculocutané et du radial, souvent manqué dans l'approche axillaire, est mieux réussi, et l'anesthésie et l'analgésie d'un nerf en particulier, innervant le site chirurgical, peut être prolongée avec un anesthésique local à longue action.

Plusieurs approches supraclaviculaires innovatrices ont été décrites au cours des années récentes: la plus récente est la technique intersternocléidomastoïdienne. En résumé, une aiguille est insérée entre les deux chefs du sternocléidomastoïdien, de la même façon que pour une canulation de la jugulaire interne mais un peu plus latéralement en direction du milieu de la clavicule. En passant derrière le sternocléidomastoïdien, l'aiguille fait contact avec le tronc supérieur du plexus brachial, rendant ce bloc préférable pour la chirurgie de l'épaule et du bras plutôt que celle de la main. Les avantages comprennent une anatomie de surface facile à reconnaître, un site de ponction loin du dôme pleural, un taux de succès élevé (93\%) et une insertion facile d'un cathéter pour le contrôle de la douleur.

Pour surmonter la nature à l'aveugle des blocs brachiaux, les nerfs cibles peuvent être localisés précisément grâce à l'échographie, évitant ainsi les risques de ponction vasculaire ou pleurale. En outre, la dispersion de l'anesthésique local dans la gaine du plexus peut être confirmée. Le rôle du guidage de l'aiguille par échographie n'a pas encore été défini.

De nouvelles informations, récemment disponibles, pourraient changer notre pratique clinique. Lorsqu'un 
bloc interscalène est réalisé pour une chirurgie de l'épaule il semble aussi fiable de rechercher une paresthésie proximale au niveau de l'épaule qu'une paresthésie distale au niveau de l'avant bras ou de la main. Traditionnellement, le bloc par voie axillaire a été considéré comme inadéquat pour la chirurgie du coude, mais une étude récente a trouvé que ce bloc axillaire entraînait une anesthésie chirurgicale adéquate chez $89 \%$ des patients opérés pour diverses opérations du coude, comparé à $78 \%$ pour le bloc supraclaviculaire et $75 \%$ pour l'interscalène. Le succès du bloc est associé à l'utilisation de marcaïne, d'adrénaline le tout couplé à une technique avec paresthésies, tout en évitant l'injection transartérielle qui est associé à des échecs. Dans l'approche axillaire, ni la pression digitale ni l'adduction du bras n'influencent la dispersion de l'anesthésique local ou le taux de succès. Des trois approches transartérielles (postérieure, antérieure, moitiémoitié), celle qui connait le moins de succès pour le bloc du nerf médian est l'approche postérieure, peut être parce que l'artère agit comme une barrière physique empêchant la diffusion de l'anesthésique au nerf médian. Enfin la dose maximale de lidocaüne utilisable pour une anesthésie du plexus brachial pourrait être plus élevée que ce qui est actuellement recommandé. Lorsqu'on injecte $900 \mathrm{mg}$ de lidocaïne contenant de l'adrénaline pour réaliser un bloc transartériel, le succès est de $100 \%$ alors que les taux sériques moyens sont de $2,9 \mu \mathrm{g} \cdot \mathrm{ml}^{-1}$ (taux toxique $>5 \mu \mathrm{g} \cdot \mathrm{ml}^{-1}$ ). Il faut cependant insister que si une telle dose est injectée par accident dans un vaisseau, de sérieuses réactions toxiques vont survenir.

\section{Blocs du membre inférieur}

L'utilisation des blocs périphériques pour la chirurgie du membre inférieur augmente. Par rapport aux blocs neuraxiaux, les blocs périphériques permettent une anesthésie unilatérale et une analgésie prolongée sans risque d'instabilité hémodynamique, de rétention urinaire et de lombalgie. Le bloc du nerf sciatique (L4S2) est utile pour la chirurgie du pied et de la cheville, le bloc fémoral (L2-4) pour l'analgésie post-arthroscopie et le bloc combiné sciatique-fémoral pour la chirurgie du membre inférieur au complet.

\section{Bloc du nerf sciatique par voie parasacrée}

Le bloc du nerf sciatique par voie parasacrée peut être considéré comme un bloc du plexus sacré unilatéral parce qu'il vise le nerf sciatique au moment où il sort du grand foramen sciatique près du plexus sacré, bloquant ainsi d'autres branches du plexus, incluant le nerf obturateur. Il est aussi plus facile techniquement par cette approche, de placer un cathéter à demeure pour le traitement de la douleur postopératoire. Plusieurs nouveaux repères osseux ont été décrits pour faciliter la localisation nerveuse.

\section{Bloc du nerf sciatique poplitée}

Les améliorations dans l'approche ont augmenté le succès du bloc du sciatique poplité. L'insertion de l'aiguille sur la ligne médiane risque plus de faire contact avec le nerf que la technique classique, où l'aiguille est insérée $1 \mathrm{~cm}$ latéralement à la ligne médiane de la cuisse en postérieur. Des variations postérieures et latérales ont été proposées au bloc du sciatique poplitée. Lors de la recherche du nerf, des réponses motrices spécifiques doivent être recherchées avec le neurostimulateur: il s'agit de la dorsiflexion et de l'inversion (due à l'action des nerfs péronier profond et tibial postérieur); la flexion plantaire et l'éversion ne sont pas des réponses motrices valables.

Parce que le nerf sciatique se divise en nerfs tibial et péroné à $8 \pm 3 \mathrm{~cm}$ au-dessus du pli poplitée, ces deux divisions peuvent ne pas être bloquées par une injection d'anesthésique à $10 \mathrm{~cm}$ au-dessus du pli poplitée (approche classique). Cependant, un bloc complet peut tout de même survenir lorsqu'une seule branche du nerf a été touchée parce qu'il existe une gaine épineurale qui entoure le sciatique et ses divisions permettant une migration céphalade et caudale dans la mesure où l'anesthésique local a été injecté dans cette gaine. Cette gaine forme aussi un conduit où placer un cathéter pour administrer une infusion d'anesthésique local pour un bloc continu du sciatique après une chirurgie du pied. Pour la chirurgie du pied, on peut aussi utiliser le nouveau bloc du compartiment réalisé en dessous du creux poplitée, et bloquant les nerfs tibial et péronier commun de façon individuelle dans des compartiments ostéofaciaux séparés.

\section{Bloc du nerf fémoral}

Le bloc du nerf fémoral, associé à une anesthésie générale légère peut réduire substantiellement les besoins en opiacés à la suite d'une réparation du ligament croisé antérieur. Cependant, lorsqu'on compare cette technique aux régimes multimodes d'analgésic systémique, le bloc fémoral continu n'ajoute aux patients aucun bénéfice après arthroplastie complète du genou. Le bloc du nerf fémoral 3 dans 1 n'anesthésie pas de façon constante le nerf obturateur mais le succès peut être amélioré en utilisant un guidage échographique. La présence d'une gaine du nerf fémoral permettant un bloc du plexus lombaire par voie paravasculaire inguinale est remise en question.

\section{Récupération rapide}

Une nouvelle utilisation des blocs périphériques des membres inférieurs peut accroître grandement la récupération. À titre d'exemple, l'utilisation de bloc des nerfs fémoral et génito-fémoral pour l'exérèse de la veine saphène interne a entraîné des récupérations 
plus rapides, moins de complications et une incidence plus faible de douleur postopératoire que l'anesthésie rachidienne. De façon analogue, le bloc sélectif du nerf poplitée et du nerf cutané postérieur de la cuisse pour l'exérèse de la saphène courte peut entraîner une anesthésie chirurgicale satisfaisante et une récupération plus rapide.

\section{Anesthésie rachidienne}

L'utilisation de la lidocaïne $5 \%$ pour l'anesthésie rachidienne a été au centre d'une controverse sur la neurotoxicité depuis quelques années. Un syndrome de la queue de cheval a été rapporté suite à une injection unique de lidocaïne 5\%. Dans les études animales in vitro, l'immersion de nerfs dans la lidocaïne 5\% a entrainé des blocs de conduction irréversibles reliés à la concentration. L'irritation radiculaire transitoire (IRT), un syndrome caractérisé par des douleurs à la région lombaire et aux jambes et survenant après l'anesthésie rachidienne, est fréquente avec la lidocaïne (16-37\%) mais non avec la bupivacaïne. L'IRT est favorisée par la position de lithotomie et la mauvaise distribution de l'agent anesthésique mais n'est pas affectée par la présence d'adrénaline et de dextrose ni par la réduction de la concentration de lidocaïne jusqu'à $2 \%$. Récemment, on a montré que la phényléphrine augmentait le risque d'IRT après anesthésie rachidienne à la tétracaïne. Même si le mécanisme n'est pas connu, on pense que l'IRT représente une forme légère de neurotoxicité. À partir de ces données cliniques et de laboratoire, la solution de lidocaïne $5 \%$ pour usage rachidien n'est plus recommandée à cette fin. Cependant, je persiste dans mon opinion que la lidocaïne demeure un agent de courte durée utile, spécialement dans le contexte ambulatoire. La recommandation actuelle est d'utiliser une solution diluée à $1,5 \%$ ou moins et de ne pas dépasser une dose totale de $100 \mathrm{mg}$, d'autres recommandant $\leq 60 \mathrm{mg}$.

\section{Solutions diluées d'anesthésique local}

Le début, la qualité et la durée d'une anesthésie rachidienne à la lidocaïne $1,5 \%$ hyperbare sont identiques sur le plan clinique à la même anesthésie réalisée avec la lidocaïne 5\%. Ce n'est que dans les études utilisant des volontaires qu'il est possible de documenter une régression du bloc sensitif et moteur plus rapide de $30 \%$ avec la lidocaïne $1,5 \%$ hyperbare. Même une solution plus diluée à $0,5 \%$ est efficace lorsque urilisée à dose faible $(25-40 \mathrm{mg})$ pour produire une anesthésie chirurgicale pour des procédures mineures gynécologiques, périrectales et urologiques. De façon surprenante, le degré de bloc anesthésique est semblable lorsqu'on utilise $70 \mathrm{mg}$ de lidocaïne même si les concentrations varient de $0,5 \%$ à $10 \%$ : les concentrations de lidocaine dans le LCR de- viennent comparables 20 minutes après l'induction sans égard à la concentration utilisée à condition que la dose totale soit la même. Récemment, le concept de la concentration anesthésique moyenne efficace (CAME) a été décrit, ce concept étant analogue à la CAM pour les agents d'inhalation. La CAME de la lidocainne hyperbare nécessaire pour produire un bloc sensitif et moteur complet chez $50 \%$ des sujets humains est de $0,54 \%$ lorsque 48 mg sont administrés, cette valeur dépendant de la dose.

La bupivacaïne isobare, d'une durée d'action prolongée, a été utilisée avec succès pour l'arthroscopie en ambulatoire. La dose recommandée est de $7,5 \mathrm{mg}$, mais le bloc qui en résulte ne donne pas constamment un bloc moteur complet de la jambe et le délai avant la première miction peut être long.

\section{Supplément opiacé}

L'ajout d'un opiacé pour supplémenter une anesthésie rachidienne $\grave{a}$ dose faible est aussi un nouveau concept. Le fait d'ajouter $25 \mu \mathrm{g}$ de fentanyl à $25 \mathrm{mg}$ de lidocaïne hypobare fournit une anesthésie adéquate pour une procédure laparoscopique de 30 minutes et entraîne une récupération sensitive et motrice de même qu'un état prêt pour le congé plus rapides que la lidocaïne conventionnelle seule. De la même façon, l'ajout de $10 \mu \mathrm{g}$ de fentanyl à 5,4 $\mathrm{mg}$ de bupivacaïne permet de réaliser une arthroscopie dans le contexte ambulatoire avec une dose faible qui serait, sans opiacé, inadéquate.

De façon traditionnelle, le fentanyl à dose faible de l'ordre de 20-25 $\mu \mathrm{g}$, est ajouté à une dose conventionnelle d'anesthésique local pour prolonger l'analgésie dans la période postopératoire immédiate. Ceci n'affecte pas la durée du bloc moteur mais peut accroître l'incidence d'hypotension et de prurit. Il est important de noter que même s'il s'agit d'une incidence rare, on a rapporté des arrêts respiratoires après $20 \mu \mathrm{g}$ de fentanyl ou $10 \mu \mathrm{g}$ de sufentanil intrathécal.

\section{Anesthésie combinée péridurale-rachidienne (CSE)}

La technique combinée péridurale-rachidienne (CSE) offre une très grande flexibilité - la rachidienne initiale apporte un début rapide de l'anesthésie et la péridurale subséquente permet une anesthésie supplémentaire durant la chirurgie selon les besoins de même qu'une analgésie postopératoire. Pour diminuer le risque d'hypotension, on utilise initialement une dose relativement faible d'anesthésique local intrathécal (vg 30-40 mg de lidocaïne). Cette combinaison a été utilisée avec succès pour diminuer les effets secondaires et le temps de congé des patients subissant une arthroscopie dans le contexte ambulatoire. Ces avantages rendent cette technique appropriée à la césarienne, à l'analgésie durant le travail et à la chirurgie du membre inférieur en ambulatoire. 


\section{Bolus périduraux}

L'injection péridurale de $15 \mu \mathrm{g}$ d'adrénaline après l'induction de l'anesthésie rachidienne demeure une dose test valable. La progression du bloc rachidien est rapide après une injection péridurale de médication. Les mécanismes d'action de cet effet incluent les suivants: 1-un transfert rapide de l'anesthésique local par le trou dans la dure-mère 2-l'existence d'une analgésie subclinique prenant toute sa puissance analgésique suite à de petits ajouts d'anesthésique local 3-une progression céphalade de l'anesthésique local contenu dans le LCR causée par la compression du sac dural par le volume de liquide injecté dans l'espace péridural. Cependant, l'impact de l'effet volume sur la progression céphalade dépend du moment de l'injection péridurale. Si le bolus péridural est donné dans les cinq minutes suivant l'injection sous-arachnoïdienne, le niveau maximal du bloc est le même qu'on ait injecté $10 \mathrm{ml}$ de salin ou $10 \mathrm{ml}$ de bupivacaïne; si le bolus survient 15-20 minutes après l'injection sous-arachnö̈dienne, la même dose de bupivacaïne va produire un bloc trois dermatomes plus haut que le salin qui lui produira un bloc deux dermatomes plus haut qu'aucune injection. Durant la régression de l'anesthésie rachidienne, seule la lidocaïne péridurale prolonge le bloc sensitif et moteur; l'injection de salin péridural peut raccourcir la durée du bloc sensitif.

\section{Risques}

Des arrêts cardiorespiratoires rapportés suite à l'administration d'opiacé durant une CSE pour césarienne ont fait naître la spéculation que les opiacés périduraux peuvent passer la dure-mère en utilisant le trou de la ponction durale. Les études réalisées à date démontrent que le taux de passage dépend de la grosseur du trou et non des propriétés physicochimiques des médicaments administrés. Par exemple, il y a peu de mouvement de médication à travers un petit trou fait avec une aiguille de calibre 24 ou 26 . La situation est différente lors d'une ponction accidentelle avec une Tuohy 18. Le risque que le cathéter pénètre dans l'espace sous-arachnoïdien par un trou fait dans la duremère est peu probable à moins que le trou soit fait par une aiguille de calibre 22 ou supérieur, ce qui a été démontré par une étude avec scopie péridurale.

\section{Anesthésie combinée péridurale et générale}

Cette approche balancée est de plus en plus utilisée pour la chirurgie majeure thoracique, abdominale ou vasculaire. L'utilisation de cette technique de façon efficace et sûre demande une attention toute particulière à la mise en place du cathéter, à l'administration de la dose test et au choix des doses de bolus.

\section{Technique de péridurale thoracique}

L'utilisation de l'anesthésie péridurale thoracique se développe en Amérique du Nord mais elle est bien établie ailleurs. Idéalement, le cathéter péridural devrait être placé aussi près que possible du site de la douleur, dans le dermatome correspondant; par exemple, pour une thoracotomie on utilise un cathéter placé dans la région de $T_{5.7}$, alors qu'on utilise un cathéter dans la région $T_{9-12}$ pour une incision abdominale spécialement si on utilise des anesthésiques locaux et/ou des opiacés liposolubles. Des difficultés techniques et le danger de traumatisme à la moelle sont les deux préoccupations majeures mais la sécurité de la mise en place de cathéters périduraux thoraciques est bien documentée. L'incidence des complications, majeures et mineures, est faible, comparable aux taux de la péridurale lombaire.

\section{Dose test péridurale}

La dose test la plus fréquemment utilisée renferme 15 $\mu \mathrm{g}$ d'adrénaline et $\mathbf{4 5} \mathrm{mg}$ de lidocaïne. Chez le patient éveillé, les changements hémodynamiques après une injection iv sont une augmentation de la fréquence cardiaque de $20 \mathrm{bpm}$ et de la pression artérielle systolique de $15 \mathrm{mmHg}$. Idéalement, on procède à la dose test avant l'induction de l'anesthésic générale. Cependant, si la dose test est administrée chez le patient endormi, la réponse est amoindrie par la dépression de la fonction cardiovasculaire produite par les agents volatils, la réponse étant en relation avec la dose. On a donc suggéré de nouvelles valeurs pour identifier une réponse positive: une augmentation de la fréquence cardiaque de $8 \mathrm{bpm}$ survenant 60 secondes après l'injection et une augmentation de la pression systolique de $>13 \mathrm{mmHg}$ après 120 secondes. Cependant, ces critères ne s'appliquent qu'à des sujets jeunes et en bonne santé recevant une anesthésie à base de $\mathrm{N}_{2} \mathrm{O}$ et d'isoflurane; les paramètres hémodynamiques de patients malades ou âgés soumis à différents régimes n'ont pas encore été définis. L'isoprotérénol à raison de $2 \mu \mathrm{g}$ est aussi un bon marqueur de l'injection $i v$, mais le potentiel neurotoxique de ce médicament n'a pas encore été vérifié.

\section{Bolus supplémentaires.}

La stabilité hémodynamique sous anesthésie générale peut être conservée en utilisant moins d'anesthésique local et plus d'opiacé pour l'analgésie péridurale. Les options sont les suivantes: bolus d'opiacés périduraux à action rapide comme le fentanyl; perfusion continue de solutions diluées d'anesthésique local, par exemple la bupivacaïne à $0,1 \%$, et d'opiacé, par exemple la morphine à $0,05 \mathrm{mg} \cdot \mathrm{ml}^{-1}$ ou le fentanyl à $4 \mu \mathrm{g} \cdot \mathrm{ml}^{-1}$. Durant l'anesthésie à l'isoflurane, des bolus périduraux de lidocaïne sont plus susceptibles d'entraîner des hypoten- 
sions que des bolus périduraux de fentanyl. Le fentanyl péridural atténue aussi l'hypertension et la toux survenant au moment de l'extubation lors du réveil.

\section{Analgésie péridurale postopératoire}

Les bénéfices cliniques de l'analgésie péridurale postopératoire quant au devenir des patients sont bien documentés. L'analgésie péridurale est supérieure à l'analgésie systémique pour contrôler la douleur au repos mais spécialement la douleur au mouvement et à la toux. Plusieurs études, mais pas toutes, rapportent une fonction cardiaque et pulmonaire améliorée par l'analgésie péridurale suite à des chirurgies majeures, thoracique, abdominale ou vasculaire.

\section{Bénéfices gastro-intestinaux}

Il existe un intérêt grandissant concernant les effets de l'analgésie péridurale sur la motilité gastro-intestinale postopératoire. À la suite de chirurgies abdominales majeures, l'iléus paralytique retarde la reprise de l'alimentation entérale pour un coût intra-hospitalier d'au moins 750 millions annuellement. Plusieurs études ont montré que les anesthésiques locaux peuvent accélérer la récupération de la fonction intestinale mais que les opiacés systémiques ou périduraux peuvent nuire à la motilité et aggraver l'iléus paralytique. Si on utilise les anesthésiques locaux seuls pour produire l'analgésie, on court un risque accru de paralysie des membres inférieurs et d'hypotension orthostatique. Mais lorsqu'on les utilise en combinaison, on a montré qu'une perfusion péridurale à dose faible de bupivacaïne et de morphine accélérait le retour du transit d'une valeur pouvant aller à 1,5 jour. Pour donner un bénéfice maximal, la thérapie péridurale doit être poursuivie durant au moins 48 heures jusqu'à la disparition de l'iléus. Les autres facteurs qui contribuent à la récupération du transit gastro-intestinal sont l'alimentation entérale précoce, l'ambulation et l'utilisation de kétorolac systémique.

\section{Opiacés périduraux}

Les opiacés utilisés pour l'analgésie péridurale ont fait l'objet d'une revue récente. Même si le fentanyl, liposoluble, n'a pas l'efficacité péridurale de la morphine, il réduit les risques de dépression respiratoire. Pour rendre les effets neuraxiaux optimaux, le site d'injection péridurale doit être aussi près que possible du dermatome correspondant au site chirurgical, par exemple une injection thoracique pour une thoracotomie. Lorsque utilisé seul en doses élevées, par exemple $80 \mu \mathrm{g} \cdot \mathrm{h}^{-1}$, l'analgésie, les effets secondaires et les taux plasmatiques sont comparables à ceux du fentanyl $i v$, suggérant une absorption systémique significative. Une analgésie d'origine neuraxiale est évidente lorsque le fentanyl est administré en faible concentration, par exemple 4 à $6 \mu \mathrm{g} \cdot \mathrm{ml}^{-1}$, et en combinaison avec des doses subanalgésiques de bupivacaïne à $0,1 \%$, démontrant ainsi une potentialisation de l'analgésie. Le sufentanil produit aussi une analgésie par voie péridurale et par voie systémique.

\section{Analgésie péridurale contrôlée par le patient (APCP)}

L'analgésie péridurale contrôlée par le patient (APCP) est un mode d'administration relativement nouveau qui fournit une analgésie équivalente à l'analgésie péridurale conventionnelle mais avec un dosage réduit et un potentiel d'effets secondaires moindres. Les patients font état d'une satisfaction accrue due en partie à la sensation de "contrôle» et due en partie à la flexibilité de pouvoir augmenter l'analgésique pour contrer la douleur accrue durant la mobilisation. Une variété d'opiacés sont efficaces, souvent administrés en bolus seulement, sans perfusion continue. Je pense cependant qu'il est prudent de débuter l'APCP avec une perfusion de base et d'ajouter des suppléments sous forme de bolus et de réduire progressivement le dosage de chacun à mesure que les besoins d'analgésie diminuent en même temps que la douleur s'estompe. Dans notre institution, nous utilisons deux mélanges de solutions péridurales contenant de la bupivacaïne à $0,1 \%$ avec ou de fentanyl à $4 \mu \mathrm{g} \cdot \mathrm{ml}^{-1}$ ou de l'hydromorphone à 0,03 $\mathrm{mg} \cdot \mathrm{ml}^{-1}$; nous débutons la perfusion à une vitesse de 4 à $8 \mathrm{ml} \cdot \mathrm{h}^{-1}$ en l'ajustant au site, les doses plus faibles allant aux cathéters thoraciques. La dose contrôlée par le patient représente en général $30 \%$ de la dose d'infusion de base horaire; les intervalles de sécurité sont de 15 à 30 minutes.

\section{Résumé}

À date, les progrès de l'anesthésie régionale en ont fait une des modalités les plus sécuritaires pour l'anesthésie et le contrôle de la douleur. Le développement et l'amélioration de nouvelles techniques de bloc et de nouvelles approches améliorent le taux de succès des blocs, la rapidité de la récupération postopératoire et la sécurité des patients. Ceci profite non seulement au soin des patients mais aussi à tout l'aspect économique des soins de santé.

\section{Références}

(Voir page R54) 